\title{
PERANAN IBU SINGLE PARENT DALAM PERKEMBANGAN SOSIAL DAN PERILAKU KEAGAMAAN REMAJA DI KELURAHAAN AEK TAMPANG KOTA PADANGSIDIMPUAN
}

\author{
Maslina Daulay \\ (Dosen Fakultas Dakwah dan Ilmu Komunikasi IAIN Padangsidimpuan) \\ email: maslina.daulay@gmail.com
}

\begin{abstract}
The background of the problems in this research are many young people in Aek Tampang District looked bad attitudes, it seemed from their social development which are more likely can damage the environment, even from the religious aspects, they avoided doing it. The single parent mothers are expected the main cause of the problems, where they are busy in financing their families. The purposes of this research are to find the role of single parent mothers in educating and developing their children, to know the social development of the young people and the religious behaviours, and to identify the effects of economic life to their mental health. It has been done qualitatively, by using interviews and observation as the instruments. Then, analysed it descriptively. The result shows that the single parent mothers are busy to earn money for their families, so, the have less time to handle, to educate, and to control their family. Although they have given their time to educate and controlled them, it looks that their children did not follow their parents. It is also found the young people are easier to be influenced by their environment, by their friends, then by their parents, and it made they also are far from the religious side.
\end{abstract}

Keywords: single parent mothers, young people, education, and bad behaviour.

\begin{abstract}
Abstrak
Latar belakang masalah dalam penelitian ini adalah di Kelurahan Aek Tampang terlihat banyak remaja yang nakal dan mengikuti pergaulan bebas, hal ini terlihat dari perkembangan sosial remaja yang lebih cenderung kepada hal-hal yang dapat merusak lingkungan, bahkan untuk pengamalan keagamaan sudah hampir dihindari oleh remaja. Adanya ibu single parent diperkirakan menjadi penyebab utama permasalahan ini, dimana ibu tersebut sibuk mencari nafkah untuk membiayai hidup keluarganya. Adapun tujuan penelitian ini adalah untuk mengetahui peranan ibu single parent di Kelurahan Aek Tampang, perkembangan sosial
\end{abstract}


70 | TAZKIR: Jurnal Penelitian Ilmu-ilmu Sosial dan Keislaman

Vol.03 No. 1 Juni 2017

remaja, perilaku keagamaan remaja di Kelurahan Aek Tampang, serta melihat pengaruh keadaan ekonomi keluarga terhadap kesehatan mental remaja. Penelitian yang digunakan yaitu dengan dilakukan secara kualitatif dengan memakai analisis secara deskriptif. Instrumen pengumpulan data yang digunakan adalah wawancara dan observasi. Hasil penelitian menunjukkan bahwa ibu single parent banyak yang sibuk mencari nafkah untuk menghidupi keluarganya, sehingga sangat sedikit waktunya untuk memperhatikan pendidikan dan melakukan pengawasan terhadap anak remajanya. Adapun orangtua yang memberikan Pendidikan dan pengawasan, akan tetapi anak remaja tersebut banyak yang tidak mematuhi perintah dan ajakan orangtuanya. Ditemukan juga bahwa remaja lebih mudah dipengaruhi oleh teman sepergaulannya daripada pengaruh orangtuanya, hal ini mengakibatkan remaja menjauhi ajaran agama.

Kata Kunci: ibu single parent, remaja, pendidikan, dan kenakalan remaja.

\section{PENDAHULUAN}

Perkembangan sosial dan pembinaan prilaku keagamaan remaja selain dipengaruhi faktor lingkungan juga sangat dipengaruhi oleh keluarga yang bersangkutan.Keluarga sangat berperan dalam mengawal perkembangan asfek sosial dan prilaku keagamaan remaja. Pemimpin dalam keluarga harus mempunyai andil yang besar terhadap remaja. Keluarga yang terdiri dari suami, istri dan anak-anak yang memiliki norma tersendiri yang harus dipatuhi oleh masing-masingg anggota keluarga dan yang berperan dominan adalah kepala keluarga.

Dengan perkembangan jaman, banyak masalah-masalah yang menjadi kompleks dan mempengaruhi keluarga-keluarga mengakibatkan munculnya struktur-struktur baru dalam keluarga. Pola pikir masyarakat tentang perkawinan dan perceraian sebagai awal dan akhir dari suatu keluarga juga mulai memudar. Pembentuka keluarga pun mulai terjadi secara sah dan tidak sah yang berujung pada perubahan struktur keluarga ada yang cerai hidup dan ada yang cerai mati. Cerai mati artinya suami yang meninggal, sehingga istrilah yang bertanggung jawab dalam kehidupan, hal seperti ini dinamakan single parent.

Single parent adalah orangtua yang telah menduda atau menjanda entah bapak atau ibu, mengasumsikan tanggung jawab untuk memelihara anak-anak setelah kematian pasangannya, perceraian atau kelahiran anak diluar nikah. 
Single parent adalah orang tua yang secara sendirian membesarkan anakanaknya tanpa kehadiran, dukungan, dan tanggung jawab pasangannya. Kesimpulannya, single parent adalah keluarga dengan hanya satu ayah atau satu ibu saja, secara sendirian membesarkan anak, memelihara, mempertahankan dan bertanggung jawab atas rumah tangganya sendiri.

Kesibukan ibu single parent dapat mengurangi perhatian terhadap anak remaja dalam hal perkembangan sosial, cara bergaul sesama remaja dalam kegiatan keagamaan seperti, sosial anak remaja dalam kegiatan hari besar Islam.

Berdasarkan pemikiran diatas perlu dilakukan penelitian tentang pengaruh ibu single parent terhadap perkembangan social dan perilaku keagamaan anak khususnya di Kota Padangsidimpuan. Adapun tujuan dari penelitian ini adalah :

a. Untuk mengetahui peranan ibu single parent terhadap remaja di Kota Padangsidimpuan.

b. Untuk mengetahui perkembangan sosial anak di Kota Padangsidimpuan.

c. Untuk mengetahui perilaku keagamaan remaja di Kota Padangsidimpuan.

\section{KAJIAN PUSTAKA}

\section{Konsep Ibu Single Parent}

Single parent adalah keluarga yang mana hanya ada satu orang tua tunggal, hanya ayah atau ibu saja. Keluarga yang terbentuk biasa terjadi pada kelurga sah secara hukum maupun keluarga yang belum sah secara hukum, baik hukum agama maupun hukum pemerintah. Konsep keluarga bukan lagi kaku secara teori konvensional bahwa kelurga terdiri dari ayah, ibu, dan anak-anak kandung. Keluarga adalah unit terkecil dari masyarakat yang terdiri atas kepala keluarga dan beberapa orang yang terkumpul dalam suatu atap dalam keadaan saling ketergantungan. ${ }^{1}$

Sedangkan Menurut Hurlock², Single parent adalah orangtua yang telah menduda atau menjanda entah bapak atau ibu, mengasumsikan tanggung jawab untuk memelihara anak-anak setelah kematian pasangannya, perceraian atau kelahiran anak di luar nikah. Sedangkan menurut Hammer \& Turner" “ A single parent family consist of one parent with dependent children living in the same household". Sejalan dengan pengertian menurut Sager et al dikutip dalam Duvall

${ }^{1}$ Depkes RI, Yang Perlu Diketahui Petugas Kesehatan tentang : Kesehatan Reproduksi, ( Jakarta,: Dipkes,2001), h: 25

${ }^{2}$ Psychologymania, 2013

${ }^{3} \mathrm{Ibid}, \mathrm{p} .3$. 
\& Miller yang menyatakan bahwa "single parent adalah orang tua yang secara sendirian membesarkan anak-anaknya tanpa kehadiran, dukungan, dan tanggung jawab pasangannya." ${ }^{4}$ Kesimpulannya, single parent adalah keluarga dengan hanya satu ayah atau satu ibu saja, secara sendirian membesarkan anak, memelihara, mempertahankan dan bertanggung jawab atas rumah tangganya sendiri. ${ }^{5}$

Ada beberapa penyebab terjadinya orang tua single parent diantaranya sebagai berikut :

\section{a. Perceraian.}

Dalam suatu perkawinan itu dibutuhkan kesepakatan untuk pembagian hak dan kewajiban dari masing-masing pihak istri maupun suami.Perceraian itu terjadi ketika salah satu atau keduanya gagal melakukan tanggung jawabnya itu.Lalu timbullah permusuhan dan kebencian sehingga tidak ada lagi jalan keluar yang dapat disepakati.Pada akhirnya salah satu atau kedua pasangan memutuskan untuk berpisah baik secara sah maupun tidak sah.

b. Kematian pasangan.

Pada hakikatnya, semua manusia pada akhirnya akan menghadapi kematian. Umur hanyalah masalah waktu sehingga kematian adalah satusatunya hal yang pasti akan terjadi dalam suatu perkawinan. Baik karena sakit, kecelakaan, bunuh diri ataupun dibunuh, pada akhirnya salah satu pihak akan meninggalkan pasangannya menjadi single parent.

\section{c. Kehamilan di luar nikah.}

Di jaman modern, kasus seperti ini sangat marak dibicarakan publik.Baik penyebabnya karena seks bebas dan si pihak lelaki tidak mau bertanggung jawab untuk menikahi si perempuan ataupun karena kasus pemerkosaan.

\section{d. Orang Tua Masuk Penjara.}

Sebab masuk penjara antara lain karena melakukan tindak kriminal seperti perampokan, pembunuhan, pencurian, pengedar narkoba atau tindak perdata seperti hutang, jual beli, atau karena tindak pidana korupsi sehingga sekian lama tindak berkumpul dengan keluarga.

\footnotetext{
${ }^{4}$ Ibid, $p$.

${ }^{5}$ Lenvinson, D.Single parents.In D. Levinson (Ed.), Encyclopedia of marriage and the family (Vol. 2, p. 666). New York, NY: Smin \& Schuster MacMillan,1995),Hlm. 12
} 


\section{e. Studi ke Pulau lain atau ke Negara Lain.}

Tuntutan profesi orang tua untuk melanjutkan study sebagai peserta tugas belajar mengakibatkan harus berpisah dengan keluarga untuk sementara waktu, atau bisa terjadi seorang anak yang meneruskan pendidikan di pulau lain atau luar negeri dan hanya bersama ibu saja sehingga menyebabkan anak untuk sekian lama tidak didampingi oleh ayahnya yang harus tetap kerja di negara atau pulau atau kota kelahiran.

Orang tua single parent berdampak terhadap anak atau remaja dimana orang tua sangat berperan terhadap perkembangan remaja khususnya Psikososial Remaja. Tentunya dalam kondisi normal orang tua masih lengkap sangat berbed dengn orang tua yang tidak lengkap. Peran orang tua sangat crucial dalam perkembangan psikososial anak. Baik sosok ayah maupun sosok ibu, dua-duanya sama pentingnya. Struktur keluarga single parent yang berbeda dari keluarga pada umumnya, tentunya menimbulkan dampak-dampak baik yang positif ataupun negatif bagi perkembangan anak.

\section{Dampak negative bagi Perkembangan Anak}

Terdapat tiga dampak negatif dari peran single parent terhadap perkembangan psikososial anak. Tiga dampak negative tersebut adalah:

a. Perubahan perilaku anak.

Dampak negative bagi perkembangan anak adalah perubahan perilaku. "Children of divorce when compared to those of intact families, have higher rates of emotional and behavioral problems, higher rates of delinquency for boys, and higher levels of anxiety and depression among preschool children" ${ }^{6}$. Sifat nakal, tidak sopan dan depresi dapat terjadi karena kurangnya waktu orang tua dengan anaknya untuk menanamkan adat istiadat atau meluangkan waktu bersama untuk bertukar pikiran.

Bagi seorang anak yang tidak siap ditinggalkan orang tuanya bisa menjadi mengakibatkan perubahan tingkah laku. Menjadi pemarah, barkata kasar, suka melamun, agresif, suka memukul, menendang, menyakiti temannya. Anak juga tidak berkesempatan untuk belajar perilaku yang baik sebagaimana perilaku keluagra yang harmonis. Dampak yang paling berbahaya bila anak mencari pelarian di luar rumah, seperti menjadi anak jalanan, terpengaruh penggunaan narkoba untuk melenyapkan segala

\footnotetext{
${ }^{6}$ Ellizabeth B. Hurlock, Psikologi Perkembangan, (Jakarta: Penerbit Erlangga,1998), h 14
} 
kegelisahan dalam hatinya, terutama anak yang kurang kasih sayang, kurang perhatian orang tua.

b. Tersesat figuritas.

Figur seorang ayah penting bagi anak perempuan dan figure seorang ibu juga penting bagi anak laki-laki. Sebagai contoh, anak laki-laki mempelajari peran ayah dari ibunya atau wanita lain, yang mampu berakibat buruk.Misalnya, si anak laki-laki menjadi kewanita-wanitaan atau lembut gemulai seperti ibunya, bisa juga karena tidak terbiasa dengan hadirnya lakilaki, si anak menjadi takut atau membenci laki-laki. ${ }^{7}$

Selain itu dampak single parent bagi anak adalah:

a. Tidak dapat melaksanakan fungsi sosialnya dengan baik sehingga anak kurang dapat berinteraksi dengan lingkungan, menjadi minder dan menarik diri.

b. Pada anak single parent dengan ekonomi rendah, biasanya nutrisi tidak seimbang sehingga penyebabkan pertumbuhan dan perkembangan terganggu.

c. Single parent kurang dapat menanamkan adat istiadat dan murung dalam seluarga, sehingga anak kurang dapat bersopan santun dan tidak meneruskan budaya keluarga, serta mengakibatkan kenakalan karena adanya ketidakselarasan dalam keluarga.

d. Dibidang pendidikan, single parent sibuk untuk mencari nafkah sehingga pendidikan anak kurang sempurna dan tidak optimal.

e. Dasar pendidikan agama pada anak single parent biasanya kurang sehingga anak jauhdari nilai agama.

f. Single parent kurang bisa melindungi anaknya dari gangguan orang lain, dan bila dalam angka waktu lama, maka akan menimbulkan kecemasan pada anak atau gangguan psikologis yang sangat berpengaruh pada perkembangan anak. ${ }^{8}$

\section{Dampak Positif Peran Orang tua Single Parent}

Terdapat tiga dampak positif dari peran single parent terhadap perkembangan psikososial anak. Dua dampak positif tersebut adalah: 1) Anak terhindar dari pertengkaran orang tua. Menonton pertengkaran orang tua

${ }^{7}$ Ali Muhammad dan Muhammad Ansori, Psikologi Remaja:Perkembangan Peserta Didik, (Jakarta:PT Bumi Akasar,2006), h. 58

${ }^{8}$ Eva Imania Eliasa, Kenakalan Remaja: Penyebab dan Solusinya. 
mampu menganggu kondisi mental seorang anak, apalagi pertengkarang yang rutin dilakukan.Anak dari single parent tidak perlu melalui moment-moment buruk seperti ini. 2) Anak menjadi lebih mandiri dan memiliki kepribadian kuat. Single parent akan lebih sering menyibukkan diri untuk bekerja mencari nafkah daripada mengurusi anaknya di rumah. Sehingga si anak sudah terbiasa untuk melakukan segalanya serba sendiri, tanpa harus didampingi. Sikap mandiri ini akan memudahkan pribadi si anak untuk ke depannya, yaitu lebih siap untuk mengarungi dunia luar yang keras. ${ }^{9}$

\section{Perilaku Keagamaan Remaja.}

Prilaku adalah tindakan, perbuatan, sikap. ${ }^{10}$ Menurut Abdul Aziz Ahyadi memberikan pengertian prilaku atau tingkah laku merupakan pernyataan atau ekspresi kejiwaan yang dapat diukur, dihitung dan dipelajari melalui alat dan metode ilmiah secara objektif. ${ }^{11}$ Jadi prilaku timbul karena adanya rangsangan dari luar diri remaja yang diperoleh melalui pengalaman dan pelajaran dengan menggunakan alat metode ilmiah secara objektif. Perilaku ini dapat dipengaruhi dari lingkungan pergaulan remaja itu sendiri. Lingkungan pergaulan remaja itu dipengaruhi dalam keluarga, lingkungan sekolah dan lingkungan teman sebaya. Kaitannya dengan perilaku keagamaan, ada beberapa ahli membahas tentang perilaku remaja sebagai berikut:

a. Menurut Freud agama adalah reaksi manusia atas ketakutannya sendiri. Tuhan adalah refleksi dari oedipus complex yaitu suatu gambaran kebencian kepada ayah yang dimanifestakan sebagai kekuatan kepada Tuhan. Agama dalam ciri-ciri psikologi adalah sebuah ilusi yakni kepercayaan yang sadar utamanya adalah angan-angan. Manusia lari kepada agama disebabkan ketidakberdayaan menghadap bencana seperti bencana alam, takut mati, keinginan manusia agar terbebas dari siksaan manusia lainnya. Dari pernyataan Freud menegaskan bahwa manusia melakukan perilaku agama semata-semata didorong keinginan untuk menghindari keadaan bahaya yang akan menimpa dirinya dan memberi rasa aman bagi diri sendiri, untuk itu manusia menciptakan Tuhan dalam pikirannya. ${ }^{12}$

\footnotetext{
${ }^{9}$ Muhammad Ansori, Psikologi Pembelajaran. (Bandung: C.V. Wacana Prima, 200, h..35

${ }^{10}$ Adi Satria, Kamus Ilmiah Populer,( Setting Data Com: Visi I 2005) h. 450

${ }^{11}$ Jalaluddin, Psikologi Agama,(Jakarta: RajaGrapindo Persada, 2007) h. 227

${ }^{12}$ Baharuddin, Pendidikan Psikologi Islam, (Bandung: Citapustaka Media, 2007) h. 2007
} 
76 | TAZKIR: Jurnal Penelitian Ilmu-ilmu Sosial dan Keislaman

Vol.03 No. 1 Juni 2017

b. Skinner merumuskan perilaku manusia adalah manusia berbuat sesuatu dalam lingkungannya untuk mendatangkan akibat, apakah untuk mendatangkan pemenuhan kebutuhan atau menghindari datangnya hukuman atau pengalaman yang tidak enak. Segala tindakan manusia dapat dimengerti dalam kerangka pikiran itu.

c. Piaget, memungkinkan remaja untuk berfikir abstrak, teoritik dan kritis juga tampak prilaku keagamaan. Mereka tidak lagi menerima saja ajaran-ajaran agama yang diberikan oleh orangtuanya. Bahkan pelajaran-pelajaran agama yang pernah mereka dapatkan pada waktu masih kanak-kanak mulai dipertanyakan, sehingga tiadak jarang menimbulkan keraguan beragama. Keraguan-keraguan berangama merupakan karakteristik perilaku beragama yang sangat menonjol pada masa remaja. Mengapa harus puasa dan sebagainya. Bahakan tidak jarang yang diragukan esensi dan tuhan sendiri. ${ }^{13}$

Berdasarkan uraian di atas bahwa perilaku keagamaan remaja bukan hanaya cendrung kepada angan-angan atau ikut-ikutan terhadap apa yang diberikan orangtuanya. Akan tetapi remaja sudah mulai mengkritis agama yang di peroleh dari orangtua dan pengalaman keagaman yang diperoleh di sekolah.

\section{Bentuk-Bentuk Prilaku Keagamaan}

Bedasarkan teori yang sudah dijelaskan sebelumnya, maka peneliti mencontohkan beberapa bentuk perilaku keagamaan yang penting bagi remaja sebagai berikut:

a. Ibadah meliputi

1. Menjalamkam shalat

Secara etimologi shalat berarti doa. Sedangkan secara terminologi adalah ibadah yang tersusun dari beberapa perkataan dan perbuatan yang dimulai dengan takbir, disudahi dengan salam dan memenuhi beberapa syarat yang di tentukan. ${ }^{14}$ Menjalankan shalat adalah kewajiban bagi seorang muslim kepada Sang Pencipta Allah Swt. Shalat efektif untuk membina manusia dan menempa nalurinya shalat memjadi pondasi hubungan antara manusia yang dibangun di atas dasar dasar yang baik dan jauh dari bias tendensi dan keinginana (hawa nafsu) sehingga manusia dapat menikmati kehidupan bahagia yang bertumpu pada semangat humanisme dan keadilan.

\footnotetext{
${ }^{13}$ Ibid. h220

${ }^{14}$ Sulaiman Rasyid, Fikih Islam, (Bandung: Sinar BaruAlgensindo,2007)h.53
} 
2. Berzdikir dan Berdoa

Zdikir secra etimologi berasal dari kata bahasa Arab dzakara, yang artinya mengingat, memperhatikan mengenang, mengambil pelajaran, mengenal tau mengerti. Sedangkan menurut terminologi dzikir sering dimaknai sebgai sesuatu amal ucapan atau amal qauliyah melalui bacaan-bacaan tertentu untuk mengingat Allah. ${ }^{15}$ Amalan dzikir dapat dibagi menjadi dua bentuk, pertama dzikir yang dipahami dan dilaksanakan oleh orang muslim pada umumnya. Disini dzkir dianggap sebgai amalan sunnah ibadah yang biasanya dilaksanakan setelah shalat lima waktu dalambentuk kegiatan pengajian berjamaah. Kedua amalan Dzikir yang dilaksanakan oleh ummat Islam yang tergabung dalam kelompok tarekat atau sufi sebagai kelompok "mistik" dalam Islam. ${ }^{23}$

Berzdikir kepada Allah adalah ibadah sunnah yang teramat mulia. Dzikir adalah peringatan doa yang paling tinggi, yang di dalamnya tersimpan banyak keutamaan dan manfaat yang besar bagi hidup dan kehidupan. Bahkan kualitas diri kita di hadapan Allah sangat di pengaruhi oleh kualitas dan kuantias dzikir kepadaN-ya. Dengan kata lain engan banyak mengingat Allah dengan tulus dan iklas karena mengharap ridhonya, maka sesunggunya kita adalah orang yang mulia dan dimuliakan Allah, sebaliknya jika kita laali dari mengingat Allah maka sesungguhnya kita termasuk golongan manusia yang sangat merungidan tak berguna. ${ }^{34}$ Dzikir biasanya dilanjutkan dengan berdoa atau memohon kepada Allah, ummat islam dengan tidak pandang derajad dan pangkat semuanya di perintahkan supaya banyak-banyak berdzikir dan berdoa kepada tuhan siang dan malam.

3. Kewajiban menutup aurat

Kata aurat dalam bahasa arab adalah kurang, jelek, buruk, atau maludari kata aurat lahirlah aurat yang artinya keji. Tapi yang diartikan aurat disini ialah bagian tubuh tidak patut dan pantas diperlihatkan kepada orang lain, kecuali kepada suaminya atau kepada hamba sahaya peremouan atau sewaktu sendirian diruangan tertutup. Menutup aurat itu merupakan faktor penunjang dari kewajiban menahan pandangan yang diperintahka Allah Swt.

${ }^{15}$ Samsul Munir Amin, Energi Dzikir Menentramkan Jiwa Mengembangkan Optimsim, (Jakarta: Amzah, 2008) h 11 
78 | TAZKIR: Jurnal Penelitian Ilmu-ilmu Sosial dan Keislaman

Vol. 03 No. 1 Juni 2017

Adapun hikmah menutup aurat antara lain sebagi berikut:

1) Wanita Islam yang menutup aurat / mengenakan busana muslimah akan memdapatkan pahal, karena ia telah melasanakan perintah Allah Swt. bahkan mendapat ganjaran pahala yang berlipat ganda, karena dengan menutup aurat ia telah menyelamatkan orang lain dari berjina mata.

2) Busana muslimah adalah identitas muslim. Dengan memakainya, yang beriman telah menempatkan identitas lahirnya, yang sekaligus membedakan seara tegas antara wanita beriman dengan wanita lainnya. Disamping itu wanita berhijab sederhana dan penuh wibawa, hingga membuat dengan orang langsung hormat, segan dan mengambil jarak antara wanita dan pria sehingga godaan bisa tercegah semaksimal mungkin. ${ }^{16}$

\section{METODOLOGI PENELITIAN}

Jenis penelitian kualitatif untuk melihat kondisi lingkungan sosial di kelurahan Aek Tampang dan untuk melihat keadaan ekonomi keluarga di kelurahan Aek Tampang dilakukan analisa secara kualitatif. Istilah subjek penelitian dipakai dalam penelitian kualitatif, pada hakekatnya sama dengan istilah populasi dan sampel dipenelitian kuantitatif. Adapun sumber data dalam penelitian terdiri dari dua sumber data antara lain: sumber data primer (20 orang remaja dan 20 orang ibu single parent) dan data sekunder data dari Kepala Desa, Ketua NNB, dan Tokoh Masyarakat). Instrumen pengumpulan data yang digunakan dalam penelitian adalah observasi dan Wawancara. Adapun tekhnik keabsahan data yang digunakan dalam penelitian ini adalah secara triangulasi, yaitu teknik pemeriksaan keabsahan data yang memanfaatkan sesuatu yang lain di luar data untuk keperluan pengecekan atau sebagai pembanding terhadap data itu. Data dianalisis dengan melakukan pengamatan, kategorisasi, penelusuran, menjelaskan hubungan, dan menarik kesimpulan.

\section{HASIL PENELITIAN DAN PEMBAHASAN.}

\section{Peranan ibu single parent terhadap remaja di Kelurahan Aek Tampang}

Adapun peran ibu single parent terhdap anak remaja sebagai berikut:

\footnotetext{
${ }^{16}$ Mahtuf Ahnan dan Maria Ulfa, h. 128
} 
a. Mendidik.

Mendidik anak merupakan tugas seorang ibu, sesuai dengan wawancara dengan ibu Dahlia Harahap bahwa saya selalu berusaha mendidik anak mulai tingkat TK, SD, SMP,SMA dan bahkan ada tambahan sekolah sore khusus pendidikan agama, hal ini didapatkan anak pada tingkat SD. Hal ini merupakan pendidikan yang didapat anak saya pada pendidikan formal. Pendidikan non formal dan pendidikan yang istimewa adalah di rumah, buat saya pendidikan ini yang harus penuh perhatian diberikan kepada anak. ${ }^{17}$

Hal ini ditambahkan oleh ibu Anna Sopiah mengatakan bahwa mendidik anak merupakan ibadah yang harus dilaksanakan dan perintah dari Allah Swt. Saya mendidik anak mempunyai tujuan yaitu menjadi anak yang sholeh dan berguna bagi orang banyak, sehingga mendapatkan kebahagiaan di dunia di akhirat. ${ }^{18}$

b. Memberikan perhatian dan kasih sayang

Melalui wawancara dengan ibu Risna mengatakan bahwa perhatian kepada anak sering dilakukan. Perhatian ini saya berikan ketika anak mendapat prestasi di sekolah, di luar sekolah dan bahkan ketika tidak mendapatkan prestasi perhatian selalu diberikan. Perhatian diberikan dengan membelikan peralatan sekolah, menasehati anak agar lebih baik hal ini diberikan ketika anak melanggar peraturan agama Islam. ${ }^{19}$ Sesuai dengan pendapat ibu Hotnida bahwa perhatian kepada anak sering dilakukan dengan anak mengajak rekreasi bersama. Ketika anak terlambat masuk rumah, saya selalu menunggu anak samapai datang bahkan mencarinya, ini merupakan bentuk perhatian. ${ }^{20}$

c. Mengadakan komunikasi

Komunikasi perlu dibangun dalam keluarga, komunikasi ibu dengan anak remaja sering dilakukan untuk mengetahui pola pikir yang ada pada anak. Hasil wawancara dengan ibu Netti Lubis bahwa selalu membangun

${ }^{17}$ Dahlia, Ibu Single Parent, Wawancara, Kelurahan Aek Tampang, Ling II, Tanggal, 02 Oktober 2015

${ }^{18}$ Anna, Ibu Single Parent, Wawancara, Kelurahan Aek Tampang, Ling II, Tanggal, 02 Oktober 2015

${ }^{19}$ Risna, Ibu Single Parent, Wawancara, Kelurahan Aek Tampang, Ling II, Tanggal, 02 Oktober 2015

${ }^{20}$ Hotnida, Ibu Single Parent, Wawancara, Kelurahan Aek Tampang, Ling II, Tanggal, 02 Oktober 2015 
80 | TAZKIR: Jurnal Penelitian Ilmu-ilmu Sosial dan Keislaman

Vol.03 No. 1 Juni 2017

komunikasi dengan anak, apalagi anaknya yang remaja berusaha berkomunikasi agar terbuka dan saya berusaha berkomunikasi sebagai teman cerita untuk berbagi dalam menyelesaikan masalah yang dihadapinya. Saya membina anak saya supaya senang berkomunikasi dengan ibunya dibanding berkomunikasi dengan temannya dan orang lain. ${ }^{21}$

d. Mencari nafkah sendirian

Mencari nafkah untuk mempertahankan hidup dan ibadah kepada Allah yang harus dilakukan oleh ibu sendirian. Melalui wawancara dengan ibu Masdelina pulungan bahwa sering memberikan penjelasan dalam mencari nafkah sendirian, diberikan penjelasan sama anak, ibu harus bisa berperan sebagai ayah dan harus kuat bisa berperan benar-benar ibu single parent. Penjelasan keadaan ini membuat anak lebih berfikir ke depan dalam memajukan kehidupan mereka. ${ }^{22}$

e. Mengajari anak

Mengajari anak kepada yang baik khusus pelajaran yang berkaitan dengan pelajaran sekolah. Mengajari anak dibarengi dengan cerita orangorang berhasil, kegunaannya agar anak tambah giat belajar dan menjadi orang pintar, sesuai dengan pepatah yaitu rajin pangkal pandai malas pangkal bodoh. Manusia tidak ada bodoh kalau mau belajar, tetapi manusia banyak yang malas, ini hasil wawancara dengan ibu Rohani. ${ }^{23}$

f. Memberikan hukuman pada anak yang nakal

Hukuman merupakan menegur dengan keras pun dapat merusak perkembangan psikologis anak. Sesuai dengan hasil wawancara denagn ibu Fatimah bahwa anak tidak dihukum, hanya dinasehati bahwa perlakuan yang diperbuat anak itu tidak baik, seperti mencuri tidak baik perbuatan yang dilarang Allah, berbohong kepada oarang lain, pergi main sama teman dan pulangnya tidak pada waktunya. Perbuatan seperti ini sebagai ibu saya hanya memberiakan nasehat pada anak. ${ }^{24}$

${ }^{21}$ Masdelina, Wawancara dengan Ibu Single Parent, Kelurahan Aek Tampang, Ling IX, Tanggal, 08 Oktober 2015

${ }^{22}$ Eni Ati, Wawancara dengan Ibu Single Parent, Kelurahan Aek Tampang, Ling II, Tanggal, 08 Oktober 2015

${ }^{23}$ Rohani, Wawancara dengan Ibu Single Parent, Kelurahan Aek Tampang, Ling II, Tanggal, 09 Oktober 2015

${ }^{24}$ Fatimah, Wawancara dengan Ibu Single Parent, Kelurahan Aek Tampang, Ling IX, Tanggal, 09 Oktober 2015 
g. Mengembangkan dan mendukung potensi anak

Melalui wawancara dengan ibu Nursyidah bahwa mendukung kemampuan anak dalam melakukan kreativitas sesuai dengan kemampuan dan kemauan anak seperti anak mempunyai bakat membaca seni alQuran, sebagai ibu berusaha mencari guru seni baca alQur,an, anak mampu renang dan senang tentu orangtua berusaha mendampingi untuk mencapai kemampuannya dalam renang tersebut. ${ }^{25}$

h. Membimbing anak memilih teman

Memilih teman perlu diperhatikan oleh orangtua, teman bisa membuat seseorang menjadi baik dan tidak baik. Sesuai dengan wawancara dengan ibu Duma Sari mengatakan bahwa berteman boleh dengan siapa saja asalkan teman itu orangnya baik. ${ }^{26}$

i. Memotivasi anak melaksanakan ibadah

Sesuai hasil wawancara dengan ibu Sabarian Batubara bahwa apabila anaknya melakukan ibadah akan diberikan hadiah supaya anak bertambah semangat dalam beribada. Anak melakukan sholat fardu dengan lengkap lima kali sehari semalam maka anak dikasih puji-pujian dan bahkan hadiah berupa beli baju sholat. ${ }^{27}$

\section{Perkembangan Sosial Remaja di Kelurahan Aek Tampang}

Hasil wawancara dari remaja menunjukkan bahwa para remaja yang ada di Kelurahan Aek Tampang sangat sedikit waktu orang tua untuk memberikan waktu kepada kami anaknya, sehingga kami sangat membutuhkan contoh teladan dari orangtua kami. Keteladanan ibu sangat penting karena seorang ibu single parent harus mampu memberikan contoh teladan pada anak-anaknya dan mampu menyediakan peluang-peluang dan saran praktis dimana remaja mampu mempraktekkan akhlak yang diterima dari orangtuanya. Oleh karena itu dalam membina dan mendidik anak remaja maka orangtuanya harus memberikan contoh dan teladan. ${ }^{28}$

Sesuai dengan hasil wawancara dengan Rinaldi mengatakan bahwa mampu menghadapi persoalan sosial, hal ini pernah terjadi dikalangan remaja seperti

\footnotetext{
${ }^{25}$ Nursyaidah, Wawancara dengan Ibu Single Parent, Kelurahan Aek Tampang, Ling II, Tanggal, 09 Oktober 2015

${ }^{26}$ Duma, Wawancara dengan Ibu Single Parent, Kelurahan Aek Tampang, Ling II, Tanggal, 10 Oktober 2015

${ }^{27}$ Observasi, tanggal,13 Oktober 2016

${ }^{28}$ Nalwan, Anak Remaja. Wawancara, Tanggal, 13 Oktober 2015
} 
82 | TAZKIR: Jurnal Penelitian Ilmu-ilmu Sosial dan Keislaman

Vol. 03 No. 1 Juni 2017

pesoalan pergaulan remaja di kelurahan Aek Tampang, ada seorang pemuda membawa ceweknya berekreasi, disaat pulang rekreasi mereka ini terlambat pulang ke rumah sudah sampai larut malam hingga menunjukkan jam 11 malam. Pemuda ini sudah melanggar peraturan yang sudah ditetapkan, bagi siapa yang melanggar peraturan konsekwensinya ada. Jadi bagi pemuda tersebut harus menerima hukuman atau denda yaitu membayar dengan uang Rp. 300.000.29

\section{Prilaku Keagamaan Remaja di Kelurahan Aek Tampang}

Adapun prilaku keagamaan Remaja antara lain:

a. Bidang Ibadah

Ibadah adalah bukti ketaatan manusia kepada Allah Swt dengan menjalankan seluruh perintah-Nya dan menjauh segala larangan-Nya. Adapun bidang ibadah yang akan di bahas dalam penelitian ini adalh sholat, puasa, zikir, do'a, dan membaca Al-qur'an.

b. Bidang Akhlak

Adapun bidang akhlak yaitu akhlak berpakain, akhlak remaja Terhadap Allah Swt, akhlak tehadap Orangtua.

\section{KESIMPULAN}

Dari hasil penelitian dapat disimpulkan bahwa Peranan ibu single parent terhadap anak remaja di Kelurahan Aek Tampang antara lain: Mendidik, memberi perhatian dan kasih sayang, mengadakan komunikasi,mencari nafkah, mengajari anak, memberikan hukuman pada anak yang nakal, mengembangkan dan mendukung potensi anak, membimbing anak memilih teman, memotivasi anak melaksanakan ibadah. Perkembangan sosial remaja di Kelurahan Aek Tampang perlu perhatian dari berbagai pihak terutama, orangtua dan didukung oleh pemerintahan setempat. Anak remaja mampu memperhatikan perkembangan sosial sehingga mereka terhindar dari perilaku yang tidak baik.

Perilaku keagamaan remaja di remaja dalam pelaksanaan shalat, ada remaja yang mengerjakan shalat lima waktu, ada yang jarang mengerjakan, dan ada juga yang benar benar tidak mengerjakan shalat. Dari segi puasa, kebanyakan dari remaja mengerjakan puasa wajib, hanya sebagian kecil remaja yang meninggalkan puasa. Zdikir, meskipun remaja tersebut mengerjakan shalat

\footnotetext{
${ }^{29}$ Rinaldi, Anak Remaja, Wawancara, Tanggal,13 Oktober 2015
} 
namun ada yang tidak berzdikir. Hanya sedikit remaja yang mau berzdkir sedangkan sebagian besar remaja lebih mementingkan berkumpul dengan temannya atau mengerjakan pekerjaan lain. Do'a, hampir dari seluruh remaja berdo'a setiap menghadapi sesuatu. Membaca al-Qur'an, hanya sedikit remaja menjadikan al-qur'an sebagai ibadah rutinnya. 
84 | TAZKIR: Jurnal Penelitian Ilmu-ilmu Sosial dan Keislaman

Vol.03 No. 1 Juni 2017

\section{DAFTAR PUSTAKA}

Adi Satria,Kamus Ilmiah Populer, Setting Dta Com, 2005.

Psikologi Agama, Jakarta: Raja Grapindo Persada, 2007

Abdul Aziz Ahyadi, psikologi agama,Banndung:Sinar Baru Algesindo, 2002

Ali Mohammad dan Muhammad Asrori, Psikologi Remaja: Perkembangan Peserta Didik. Jakarta: P.T. Bumi Aksara, 2006.

Abuddin Nata, Manejemen Pendidikan, Mengatasi kelemahan Pendidikan Islam Di indonesia,Jakarta: Kencana, 2003

Baharuddin, Pendidikan Psikologi Islam, Bandung: Citapustaka Media, 2007

Baharuddin Jalaluddin dan Buyung Sihombing, Metodologi Study Islam,Bandung, Cipta Pustaka Media, 2005

Dadang Kahmad,Sosiologi Agama, Bandung: Remaja Rosdakarya, 2002

Depkes RI, Yang Perlu Diketahui Petugas Kesehatan tentang : Kesehatan Reproduksi,Depkes, Jakarta: 2001)

Ellizabeth B. Hurlock, Psikologi Perkembangan, Jakarta: Penerbit Erlangga,1998

Eva Imania Eliasa, Kenakalan Remaja: Penyebab dan Solusianya.

Elida Prayitno. Psikologi Dewasa, Padang: Angkasa Raya,2006

Muhammad Ansori, Psikologi Pembelajaran. Bandung: C.V. Wacana Prima, 2009.

Ramayulis, Psikologi Agama, Jakarta: Kalam Mulia, 2013

Suririn, ilmu Jiwa Agama, Jakarta: Raja Grafindo Persada, 2004 